\title{
Ingestion and ejection of hooks: effects on long-term health and mortality of angler-caught yellowfin bream Acanthopagrus australis
}

\author{
Matt K. Broadhurst ${ }^{1, *}$, Paul A. Butcher ${ }^{1}$, Craig P. Brand ${ }^{1}$, Mark Porter ${ }^{2}$ \\ ${ }^{1}$ New South Wales (NSW) Department of Primary Industries, Fisheries Conservation Technology Unit, PO Box J321, \\ Coffs Harbour, New South Wales 2450, Australia \\ ${ }^{2}$ Ridley Aqua-Feed Pty Ltd, PO Box 187, Deception Bay, Queensland 4508, Australia
}

\begin{abstract}
Ninety juvenile yellowfin bream Acanthopagrus australis were angled from holding tanks, allowed to ingest nickel-plated, carbon-steel J-hooks and released (with their lines cut) into individual experimental tanks during 2 experiments in order to assess their (1) long-term (up to $105 \mathrm{~d}$ ) health, mortality and rate of hook ejection and (2) short- and medium-term $(<42 \mathrm{~d})$ temporal changes in health during hook ingestion. Equal numbers of control fish were scooped from holding tanks and similarly monitored in experimental tanks. Of 20 hook-ingested fish released during Expt 1, 3 died within $8 \mathrm{~d}$, providing a non-significant mortality of $15 \%$. Between Day 6 and Day 56 post-release, 13 of the surviving individuals ejected their hooks, which were typically oxidized to about $94 \%$ of their original weight and often broken into 2 pieces. At Day 105, there were no significant differences between the 20 control and 17 hook-ingested/-ejected fish in terms of their ability to digest and assimilate food (measured as changes in apparent digestibility coefficients), stress (measured as concentrations of plasma cortisol and glucose) or of morphological parameters that included weight (Wt) and maximum height (MH), maximum width (MW) and maximum girth (MG). During Expt 2, 3 individuals that still contained ingested hooks and 3 controls were sampled on each of 9 occasions between Day 3 and Day 42 post-release. All fish were sampled for blood cortisol and glucose and were then euthanized before being weighed and measured for total length (TL), MH, MW and MG. Hook-ingested individuals were also X-rayed to determine the position and orientation of hooks. There were no significant differences in plasma glucose between hook-ingested and control fish. Irrespective of the treatment of fish, concentrations of cortisol were elevated on some sampling occasions, indicating variable, acute stress. The MH and MG of fish were not significantly different between groups. Significant differences were detected for MG and $\mathrm{Wt}$, with hook-ingested fish having weights similar to those of the control fish but a relatively greater MW (owing to stomach distension from ingested hooks) until 2 wk post-release, after which both morphological parameters generally declined. There was no significant temporal progression of hooks in the stomach of treatment fish; however, some hooks reorientated to positions that may have precluded passage along the digestive tract. We conclude that, for the J-hooks examined, cutting the line is an appropriate strategy that results in the greater majority of released hook-ingested yellowfin bream surviving with minimal negative long-term effects.
\end{abstract}

KEY WORDS: Acanthopagrus australis $\cdot$ Catch-and-release $\cdot$ Hook mortality $\cdot$ Hook ingestion Resale or republication not permitted without written consent of the publisher

\section{INTRODUCTION}

Recreational fisheries are important throughout Australia, with more than 3 million participants (or up to $20 \%$ of the total population) catching approximately
137 million aquatic animals comprising 230 species, and contributing to an associated gross expenditure of about \$AU 1.8 billion each year (Henry \& Lyle 2003). Anglers (fishers using hook and line) are responsible for the majority of this effort ( $>70 \%$ ), which is mainly 
directed towards coastal, estuarine and freshwater teleosts. With a total catch of 13 million ind. $\mathrm{yr}^{-1}$ (Henry \& Lyle 2003), breams (Sparidae) are among the most highly sought species, and especially yellowfin bream Acanthopagrus australis, which is targeted throughout its distribution in estuaries and near-shore habitats between southern Queensland and Victoria (West \& Gordon 1994, Broadhurst et al. 2005).

Like many recreational fish in Australia, yellowfin bream are managed by minimum size limits (23 to $26 \mathrm{~cm}$ total length, TL) and, in some states, daily quotas (10 to 20 fish person $\left.{ }^{-1}\right)$. These regulations, combined with the growing practice of catch-and-release angling, contribute towards a $63 \%$ release of all bream (Henry \& Lyle 2003). For existing management regulations to be effective, many of these released individuals need to survive. Concerns over the potential for large unaccounted recreational fishing mortalities of yellowfin bream have resulted in preliminary assessments of their post-release fate, the results of which have been promising (Broadhurst et al. 1999, 2005, Butcher et al. 2007, this volume). For example, during a recent catch-and-release event involving conventional angling practices, Broadhurst et al. (2005) observed overall short-term $(<5$ d) mortalities of between 8 and $28 \%$.

As with many other species released by anglers worldwide (reviewed by Muoneke \& Childress 1994, Bartholomew \& Bohnsack 2005), anatomical hook location has been identified as a major predictor of mortality in yellowfin bream, with fewer than $4 \%$ of mouthor jaw-hooked fish dying, compared with more than $45 \%$ of those that ingest hooks (Broadhurst et al. 1999, 2005). Further, as in related studies of other species (Hulbert \& Engstrom-Heg 1980, Schisler \& Bergersen 1996, Taylor et al. 2001, Aalbers et al. 2004), Butcher et al. (2007) observed a clear interaction between hook ingestion and subsequent removal (by hand) for yellowfin bream: the latter causing $88 \%$ mortalities compared with no deaths when hook-ingested fish were released with their lines cut.

While the above results suggest a clear strategy for mitigating the mortality of hook-ingested yellowfin bream (i.e. by cutting the line and releasing the fish), they are limited to very short monitoring periods. The few primary literature studies that have examined more longer-term consequences of leaving ingested hooks in fish are mainly limited to salmonids (but see Aalbers et al. 2004, Tsuboi et al. 2006), and support a general pattern whereby most mortalities occur within the first $24 \mathrm{~h}$ after release, followed by ongoing hook ejection from surviving fish over up to 2 mo (Hubert \& Engstrom-Heg 1980, Schill 1996, Schisler \& Bergersen 1996). For example, Schill (1996) observed that $47 \%$ of released hook-ingested rainbow trout Oncorhynchus mykiss died and $74 \%$ of the surviving fish ejected their hooks over 60 d. Similarly, Schisler \& Bergersen (1996) reported mortalities of approximately $21 \%$ and a hook ejection rate of $25 \%$ over $21 \mathrm{~d}$ for the same species.

As well as observed mortalities, there may also be subtle, long-term effects on the health of surviving hook-ingested/-ejected fish that could affect their reproduction or growth and/or increase their susceptibility to predation, infection and ultimately some unaccounted mortality (Pickering \& Pottinger 1985, Ryer et al. 2004). Such effects have not been examined in detail and are restricted to comparisons of simple condition indices or changes in total length (Mason \& Hunt 1967, Hugbert \& Engstom-Heg 1980, Schill 1996, Jenkins 2003, Aalbers et al. 2004). Many relevant assessments have not demonstrated significant differences between hook-ingested and control fish; however, Jenkins (2003) did identify a relatively slower growth rate in rainbow trout that ingested J-hooks compared with control and other treatment fish at the end of a $26 \mathrm{~d}$ experiment. The potential for these subtle longer-term effects warrant more detailed investigation across regular temporal scales during any study that seeks to provide a comprehensive assessment of the fate of hook-ingested fish.

The above sorts of protracted health-related impacts on surviving hook-ingested fish may be considered as tertiary or whole-animal stress responses (e.g. Wedemeyer \& McLeay 1981, Carragher \& Rees 1994, Barton 1997 ) and, as a precursor to changes in growth or morphological condition, could manifest as a reduced ability to consume, digest and assimilate food. One method of assessing the potential for these latter effects is to include known concentrations of inert compounds like chromic oxide $\left(\mathrm{Cr}_{2} \mathrm{O}_{3}\right)$ in the diets of hook-ingested and control fish, to sample faecal matter in their digestive tracts and then use the $\mathrm{Cr}_{2} \mathrm{O}_{3}$ as an indicator to calculate and compare apparent digestibility coefficients (ADCs) for dry matter and key nutrients (e.g. Austreng 1978, Cho \& Kaushik 1990, Allan et al. 1999). Also, because tertiary stress responses can have tractable relationships with more short-term physiological changes in fish (Pickering et al. 1982), these can provide insight into the ongoing severity of particular stressors. Fish initially respond to stress via stimulation of their nervous and endocrine systems and the release of steroids (i.e. adrenaline and cortisol), followed by secondary effects that include changes to blood cell homeostasis (Mazeaud et al. 1977, Wedemeyer \& McLeay 1981, Carragher \& Rees 1994). Reliable indices of stress include plasma cortisol and metabolites such as glucose, providing that appropriate baseline levels are available (Pankhurst \& Sharples 1992, Barton 1997).

Given the above, our first aim in this study was to estimate the long-term health and mortality (up to 
$15 \mathrm{wk}$ ) of hook-ingested yellowfin bream and their rate of hook ejection. Because the presence of ingested hooks could conceivably evoke negative physiological responses in fish, our second aim was to quantify shortto medium-term $(<6 \mathrm{wk})$ temporal changes in the health of those fish still containing ingested hooks.

\section{MATERIALS AND METHODS}

Two experiments were done at the National Marine Science Centre, Coffs Harbour, Australia, between April and October 2005 using approximately 1600 yellowfin bream, six 30001 holding tanks, up to fifty-eight 1101 experimental tanks, and approximately 300 nickel-plated carbon-steel hooks (Fig. 1). The hooks were conventional J-designs commonly used to catch yellowfin bream (Broadhurst et al. 2005), with 2 barbs cut into the shaft and designed to secure baits (Fig. 1). Before being used, all hooks were weighed to the nearest $0.0001 \mathrm{~g}$. All tanks were supplied with flowthrough seawater (ambient temperature 18.3 to $22.4^{\circ} \mathrm{C}$ ) at a rate of $30 \mathrm{l} \mathrm{min}^{-1}$ and aerated using stone diffusers. The 1101 tanks were distributed throughout an enclosed room and maintained under an artificial photoperiod (light:dark ratio 12:12 h).

Yellowfin bream used in the experiments. Before starting each experiment, approximately 800 yellowfin bream (16 to $29 \mathrm{~cm}$ TL) were caught in the Clarence River $\left(29^{\circ} 26^{\prime} \mathrm{S}, 153^{\circ} 22^{\prime} \mathrm{E}\right)$ using twin trawls rigged with codends made from $25 \mathrm{~mm}$ knotless polyamide mesh towed for less than $10 \mathrm{~min}$ in shallow water (between 5 and $12 \mathrm{~m}$ ). At the end of each tow, live yellowfin bream were collected, transported and placed into 5 of the $3000 \mathrm{l}$ tanks (approximately 100 ind. $\operatorname{tank}^{-1}$ ) as per the methodologies described by Broadhurst et al. (1999). Fish were allowed to acclimatize for between 1 and $4 \mathrm{mo}$, during which time they were fed a diet of school prawns Metapenaeus

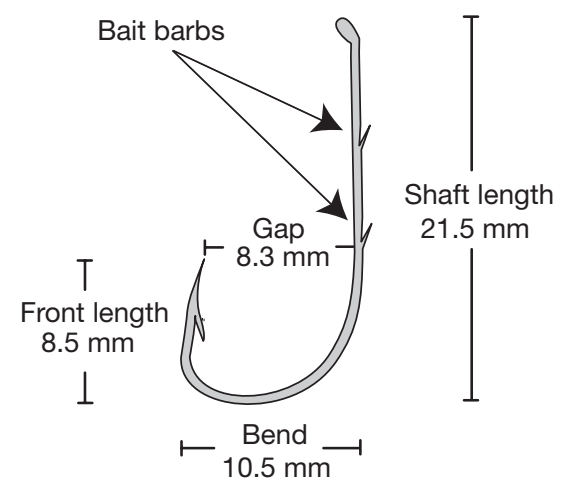

Fig. 1. Nominal measurements of J-hooks used during the present study macleayi and $4 \mathrm{~mm}$ commercial pellets at a rate of $1 \%$ biomass $\mathrm{d}^{-1}$. Any dead fish were removed daily.

On the 1st day of both experiments, 3 yellowfin bream were hooked from each of the five $3000 \mathrm{l}$ tanks containing fish (a total of 15 fish) and sampled for blood according to the methodology described by Broadhurst et al. (2005), before being released into the empty 6th 30001 tank. Blood samples were processed and analysed for plasma glucose and cortisol following the methods of Moore (1983) and Pankhurst \& Sharples (1992), respectively.

Expt 1: rates of long-term survival and hook ejection. Twenty yellowfin bream from 3 of the five 30001 tanks containing fish were allowed to ingest single hooks attached to $3.6 \mathrm{~kg}$ monofilament line and baited with school prawns. After ingestion, fish were allowed to fight for $15 \mathrm{~s}$ before being pulled from the tanks, held in one hand while the line was cut approximately $5 \mathrm{~cm}$ from the mouth (as per conventional practices), and then released individually into 20 of the 1101 tanks (all within $30 \mathrm{~s}$ ). Any mouth-hooked fish were released into the 6th $3000 \mathrm{l}$ tank and not used in the experiment. A second hook (termed a 'tank hook') was placed into a $70 \mathrm{ml}$ perforated cylindrical plastic container that floated on the surface of each tank. These hooks were used to test the hypothesis that rates of oxidation did not differ between ingested and non-ingested hooks (see below). Immediately after the last hook-ingested yellowfin bream was released, 20 control fish were randomly scooped from the remaining 2 unfished 30001 holding tanks and placed individually into 20 separate $110 \mathrm{l}$ experimental tanks. Tank hooks were placed into perforated plastic containers in each tank (to control for any potential confounding effects of hooks floating in treatment tanks).

The 20 hook-ingested and 20 control fish were fed $4 \mathrm{~mm}$ commercial pellets supplemented with $\mathrm{Cr}_{2} \mathrm{O}_{3}$ $(0.5 \%$ ) (for use in determining $\mathrm{ADCs}$; see below) at a rate of 1 pellet $\mathrm{d}^{-1}$, and monitored daily over $105 \mathrm{~d}$ for any mortalities. Fish that died were removed from the tanks, along with their corresponding tank hook. Any ejected hooks or fragments were also collected and immediately removed along with the corresponding tank hook. At the end of the experiment, all surviving hook-ingested/-ejected and control fish were removed from their tanks and sampled for plasma cortisol and glucose before being euthanized in a solution of benzocaine (100 $\mathrm{mg} \mathrm{l}^{-1}$ in seawater).

The euthanized hook-ingested/-ejected and control fish were immediately weighed (to the nearest $0.01 \mathrm{~g}$ ), sexed where possible, and measured for TL, maximum height $(\mathrm{MH})$ maximum width $(\mathrm{MW})$ and maximum girth (MG) (all to the nearest $1 \mathrm{~mm}$ ) according to descriptions provided by Broadhurst et al. (2006). Those fish that still contained ingested hooks were lat- 
erally X-rayed before all individuals were dissected. Any ingested hooks were removed and, along with ejected hook fragments and the corresponding tank hooks (for hook-ingested fish only), cleaned of all oxidized metal (using a scourer) and weighed.

The intestines of all euthanized hook-ingested and control fish were removed and evenly separated into posterior and anterior sections, and their contents dried at $70^{\circ} \mathrm{C}$ for $24 \mathrm{~h}$ before being stored frozen prior to chemical analyses. To provide sufficient matter for analyses, samples of each intestinal section from hookingested/-ejected and control fish were pooled across 2 or 3 individuals. Chemical analyses of dry matter, protein and chromic oxide were done on the pooled samples, following the procedures outlined by AOAC (1975) and Scott (1978). Using $\mathrm{Cr}_{2} \mathrm{O}_{3}$ as the inert indicator, ADCs for dry matter and protein were derived according to the general formula provided by Cho \& Kaushik (1990)

$$
\mathrm{ADC} \text { for dry matter }=\left[1-\left(D_{\mathrm{Cr}} / F_{\mathrm{Cr}}{ }^{1}\right)\right] \times 100
$$

and

$$
\mathrm{ADC} \text { for protein }=\left[1-(F / D)\left(D_{\mathrm{Cr}} / F_{\mathrm{Cr}}\right)\right] \times 100
$$

where $D_{\mathrm{Cr}}$ is $\% \mathrm{Cr}_{2} \mathrm{O}_{3}$ in the diet, $F_{\mathrm{Cr}}$ is $\% \mathrm{Cr}_{2} \mathrm{O}_{3}$ in the faeces, $F$ is \% protein in the faeces and $D$ is \% protein in the diet.

Expt 2: temporal monitoring of the health of hookingested yellowfin bream. On the 1st day of the experiment, 29 hook-ingested and 29 control yellowfin bream were released into individual $110 \mathrm{l}$ experimental tanks, as per the methods described above. Hooks were similarly placed into perforated, plastic containers that were floating at the surface of each tank. All fish were monitored and fed one $4 \mathrm{~mm}$ commercial pellet daily. Three replicate yellowfin bream with hooks still ingested and 3 controls were then randomly and lethally sampled from the $110 \mathrm{l}$ tanks on 9 occasions (every $3 \mathrm{~d}$ until Day 18, and then on Days 26, 34 and 42 post-release). To provide sufficient replication, fish that ejected their hooks or died before being sampled were removed (along with a corresponding control) from the experiment, sexed and measured for TL. The required number of hook-ingested and control fish were then angled or scooped (respectively) from the relevant $3000 \mathrm{l}$ tanks and released into the $110 \mathrm{l}$ experimental tanks.

On each sampling occasion, the 3 hook-ingested and 3 control fish were scooped from their tanks and immediately sampled for blood (and plasma cortisol and glucose) as outlined above. All 6 fish were euthanized, sexed, weighed and measured for $\mathrm{TL}, \mathrm{MH}, \mathrm{MW}$ and MG as outlined above. Treatment fish were laterally $\mathrm{X}$-rayed. The X-rays were used to determine the 2dimensional orientation (to the nearest $90^{\circ}$ ) and rela- tive position of ingested hooks. The latter was standardized by dividing the TL of each fish by the distance between the mouth and the anterior edge of each hook, irrespective of its orientation in the digestive tract. After fish were X-rayed, the ingested hooks were removed and, along with the corresponding tank hooks, cleaned of all oxidized metal (using a scourer) and weighed.

Statistical analyses. Data were analysed separately within each experiment. Size-frequency distributions (1 cm TL intervals) of hook-ingested and control fish were compared using 2-sample Kolmogorov-Smirnov tests. Two-tailed Fisher's exact tests were used to determine if (1) sex and (2) mortality were independent of the treatment of fish (hook-ingested vs. control). The null hypothesis $\left(H_{0}\right)$ of an equal sex ratio was examined using a chi-squared goodness-of-fit test.

Student's $t$-tests were used to compare (1) the ADCs of dry matter and protein calculated for hookingested/-ejected and control fish and (2) proportions of nonoxidized hooks or fragments (calculated by dividing the original weight by the sampled hook weight) ejected by fish and in the corresponding tanks in Expt 1. For Expt 2, the proportion of ingested and tank hooks remaining on each sampling occasion were compared using a balanced 2-factor ANOVA, with sample time and hook location (ingested vs. tank) considered fixed factors. A 1-factor ANOVA was used to test for differences in the relative position of hooks in $\mathrm{X}$-rayed treatment fish across the 9 sample periods in Expt 2.

ANOVA was also used to examine differences in mean concentrations of glucose $\left(\mathrm{mmol} \mathrm{l}^{-1}\right)$ and cortisol $\left(\mathrm{ng} \mathrm{ml}^{-1}\right)$ in the blood plasma of (1) fish randomly collected from the five $3000 \mathrm{l}$ tanks at the start of each experiment, (2) the surviving control and hookingested/-ejected fish at the end of Expt 1, and (3) the surviving control and hook-ingested fish that retained hooks and were sampled on each of the 9 sampling occasions during Expt 2. Balanced and unbalanced 1-factor models were used for (1) and (2), above, respectively, while the third analyses involved a balanced 2-factor model (with treatment of fish and sample time considered fixed factors). Prior to all ANOVAs, data were first tested for heterogeneity using Cochran's test and, if required, appropriately transformed. Raw means are presented for ease of interpretation. In cases where there was a missing replicate for some of the balanced analyses, this replicate was replaced with the cell mean and the residual degrees of freedom were adjusted accordingly (Underwood 1981).

The $H_{0}$ that no differences in morphological measurements ( $\mathrm{MH}, \mathrm{MW}, \mathrm{MG}$ and $\mathrm{Wt}$ ) would be observed between hook-ingested/-ejected and control fish at the end of Expt 1, or among the 3 replicates of hook- 
ingested and control fish on each of the 9 sampling occasions during Expt 2, was tested using multivariate and univariate analyses of co-variance (MANCOVA and ANCOVA). All data were ln-transformed, with ln TL as the co-variant. The full models (1- and 2-factor for each experiment, respectively) were tested first and any non-significant interaction terms sequentially removed prior to re-testing. Non-significant interactions between the measured (dependant) variables and the covariate (ln TL) implied parallelism in the relationship. For all analyses, $H_{0}$ was rejected at $\mathrm{p}<0.05$.

\section{RESULTS}

\section{Yellowfin bream collected for the experiments}

Of the 1600 yellowfin bream collected from the Clarence River, approximately 200 died, providing an overall mortality of approximately $12.5 \%$. Most deaths occurred within $2 \mathrm{~d}$ after being placed into the $3000 \mathrm{l}$ tanks. There were no mortalities of fish during the $5 \mathrm{~d}$ before either experiment started.

\section{Expt 1: rates of long-term survival and hook ejection}

There were no significant differences in size composition between the 20 hook-ingested (mean \pm SE: $21.21 \pm 0.75 \mathrm{~cm} \mathrm{TL})$ and 20 control $(21.30 \pm 0.74 \mathrm{~cm} \mathrm{TL})$ yellowfin bream (Kolmogorov-Smirnov test, $\mathrm{p}>0.05$ ). Similarly, gender was independent of the treatment of fish (Fisher's exact test, $p>0.05$ ), and the overall ratio was not significantly different from 1:1 $\left(\chi^{2}=0.00, p>\right.$ $0.05)$.

All of the control fish survived. In contrast, 3 of the hook-ingested fish died (on Days 1, 2 and 8 postrelease, respectively, Fig. 2), providing a nonsignificant mortality rate of $15 \%$ (Fisher's exact test, $\mathrm{p}>0.05$ ). Of the 17 surviving hook-ingested fish, 13 $(76 \%)$ ejected their hooks between Days 6 and 56 postrelease (mean \pm SE: $19.78 \pm 4.12$ di Fig. 2). In $54 \%$ of cases, hooks were broken into 2 pieces at the bait barbs on the shaft (Fig. 1). Hooks and line were also observed being passed from the anuses of 2 individuals on Days 5 and 12 post-release. The ejected hooks were oxidized to a mean of $93.66 \pm 1.04 \%$ of their original weight, which was not significantly different to tank hooks $(89.35 \pm 3.10 \%$ of their original weight) (data were arcsine-root transformed, $t$-test, $\mathrm{df}=24, \mathrm{p}>$ 0.05). The 4 fish that still contained their hooks after $105 \mathrm{~d}$ showed no visual evidence of peritonitis or infection. All 4 hooks were located within the stomach wall and had oxidized to a mean of $95.54 \pm 2.88 \%$ of their original weight.
There were no significant differences in mean ADCs of protein and dry matter from either the anterior (untransformed data, $t$-test, $\mathrm{df}=5, \mathrm{p}>0.05$ ) or posterior ( $t$-test $, \mathrm{df}=9, \mathrm{p}>0.05)$ intestines of euthanized hookingested/-ejected and control fish. The subsequent pooled mean \pm SE ADCs for protein and dry matter were $34.04 \pm 5.04$ and $23.58 \pm 4.2$, respectively, for the anterior intestine and $55.96 \pm 3.41$ and $43.63 \pm 3.58$, respectively, for the posterior intestine. These results indicate that food was similarly consumed and assimilated by both groups of fish. In support of this, the overall physical condition of hook-ingested/-ejected and control fish remained the same. Specifically, the full MANCOVA model of ln-transformed morphological measurements with $\ln$ TL as a covariate failed to detect a significant first-order interaction (Wilks' $\lambda_{4,30}=0.84$, $\mathrm{p}>0.05$ ). This interaction was then removed from the model and the data reanalysed. While the effects of the covariate were significant $(p<0.01)$, there were no subsequent significant main effects of the treatment of fish detected in the revised MANCOVA (Wilks' $\lambda_{4,31}=$ $0.89, \mathrm{p}>0.05$ ) or in the individual ANCOVAs for $\mathrm{MH}$ $\left(F_{1,34}=0.90, \mathrm{p}>0.05\right), \mathrm{MW}\left(F_{1,34}=0.05, \mathrm{p}>0.05\right), \mathrm{MG}$ $\left(F_{1,34}=1.76, \mathrm{p}>0.05\right)$ or Wt $\left(F_{1,34}=3.04, \mathrm{p}>0.05\right)$.

There were no significant differences in the raw levels of plasma cortisol $\left(F_{4,10}=0.66, \mathrm{p}>0.05\right)$ or glucose $\left(F_{4,10}=0.35, \mathrm{p}>0.05\right)$ in the fish sampled from the five $3000 \mathrm{l}$ tanks at the start of the experiment. The pooled means \pm SE were $37.99 \pm 7.57 \mathrm{ng} \mathrm{ml}^{-1}$ and $2.01 \pm$ $0.19 \mathrm{mmol} \mathrm{l}^{-1}$, respectively. Further, these concentrations of cortisol and glucose (pooled across tanks) were not significantly different to those in hook-ingested/ -ejected $\left(20.27 \pm 7.86 \mathrm{ng} \mathrm{ml}^{-1}\right.$ and $2.69 \pm 0.26 \mathrm{mmol} \mathrm{l}^{-1}$, respectively) and control $\left(22.11 \pm 5.15 \mathrm{ng} \mathrm{ml}^{-1}\right.$ and $2.34 \pm 0.21 \mathrm{mmol} \mathrm{l}^{-1}$, respectively) yellowfin bream at the end of the experiment $\left(F_{2,46}=1.98, \mathrm{p}>0.05\right.$ and $F_{2,45}=2.27, \mathrm{p}>0.05$, respectively).

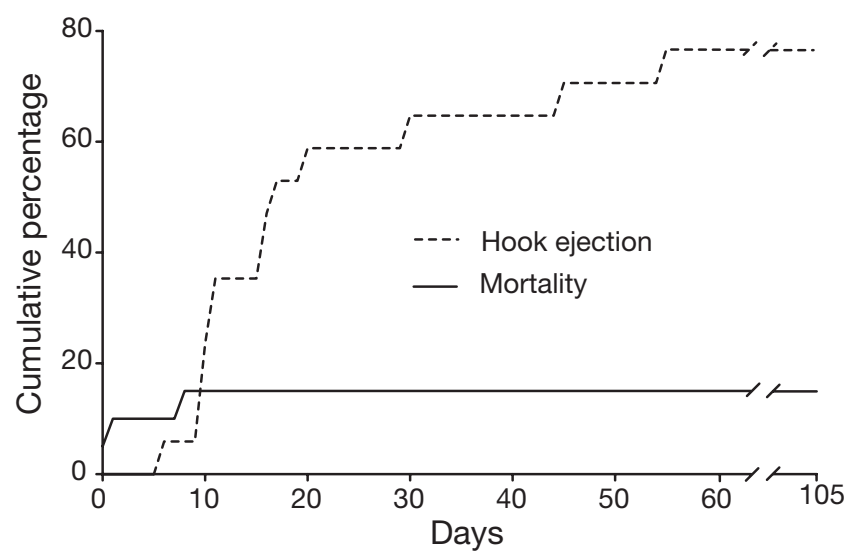

Fig. 2. Acanthopagrus australis. Cumulative percentage hook ejection and mortality of hook-ingested yellowfin bream during Expt 1 


\section{Expt 2: temporal monitoring of the health of hook- ingested yellowfin bream}

A total of 70 hook-ingested and 70 control yellowfin bream were released into the $110 \mathrm{l}$ tanks during Expt 2. The size compositions of these groups (21.51 \pm 0.29 and $22.35 \pm 0.28 \mathrm{~cm} \mathrm{TL}$ ) were not significantly different (Kolmogorov-Smirnov test, $p>0.05$ ). For 29 individuals that could be sexed, there was no dependency of gender on the treatment of fish (Fisher's exact test, $p>0.05)$, but there was a bias in the pooled ratio of males to females $\left(1: 4.8, \chi^{2}=12.45, \mathrm{p}>0.05\right)$.

Three control fish died on Days 14, 15 and 35, respectively, after being released into the $110 \mathrm{l}$ tanks. Of the 70 hook-ingested fish that were released, 24

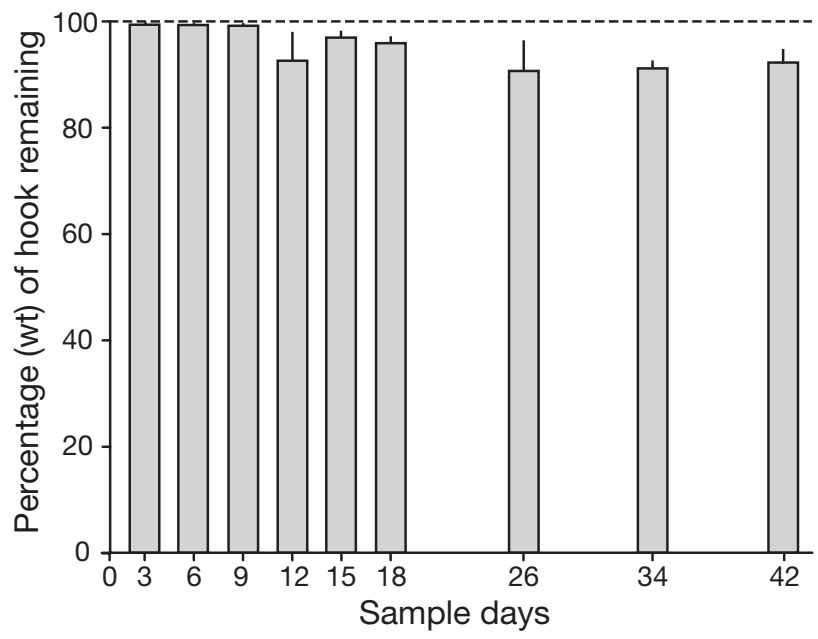

Fig. 3. Acanthopagrus australis. Differences in mean $\pm \mathrm{SE}$ percentages of hooks remaining (by weight) pooled among treatment fish and their tanks on 9 sampling occasions during Expt 2 died within 10 min to $23 \mathrm{~d}, 19$ ejected their hooks between Days 3 and 33, and 27 were successfully sampled with their hooks still ingested. Because these 3 groups of fish and their controls were removed from the experiment and then replaced (where required) with other hook-ingested fish and controls at different times, it was not possible to determine long-term rates of hook ejection or mortality; however, the latter was apparently greater than that observed in Expt 1.

Two-factor ANOVA did not detect a significant difference in the rates of oxidation between ingested (pooled mean: $95.82 \pm 0.01 \%$ of their original weight) and tank hooks $(94.69 \pm 0.02 \%)$ for the 27 hookingested yellowfin bream across the 9 sample times (arcsine-root transformed data, $F_{1,35}=0.00, \mathrm{p}>0.05$ ). Similarly, there was no interaction between hook location and sample time $\left(F_{8,35}=0.76, \mathrm{p}>0.05\right)$ although the latter term did have a significant main effect $\left(F_{8,35}\right.$ $=3.37, \mathrm{p}<0.01$ ), with all hooks showing greater rates of oxidation over time, irrespective of their location (Fig. 3). The relative position of hooks did not significantly deviate $\left(F_{8,18}=0.26, \mathrm{p}>0.05\right)$ from a mean of $(0.27 \pm 0.01) \times \mathrm{TL}$ posterior to the snout over the $9 \mathrm{sam}-$ pling occasions (Fig. 4). In contrast, there was some evidence of temporal variability in the orientation of ingested hooks in the digestive tract (Fig. 4). During the first $18 \mathrm{~d}$, most hooks were horizontally positioned with the barb below the shaft, before assuming a more varied range of vertical and horizontal orientations between Days 26 and 42 post-release (Fig. 4). In nearly all cases, the hooks were located on the same lateral plane as the fish. There was no visual evidence of any infection associated with the presence of the hooks.

The full MANCOVA model of ln-transformed morphological measures had neither a significant secondorder interaction (Wilks' $\lambda_{32,56}=0.09, \mathrm{p}>0.05$ ) nor a

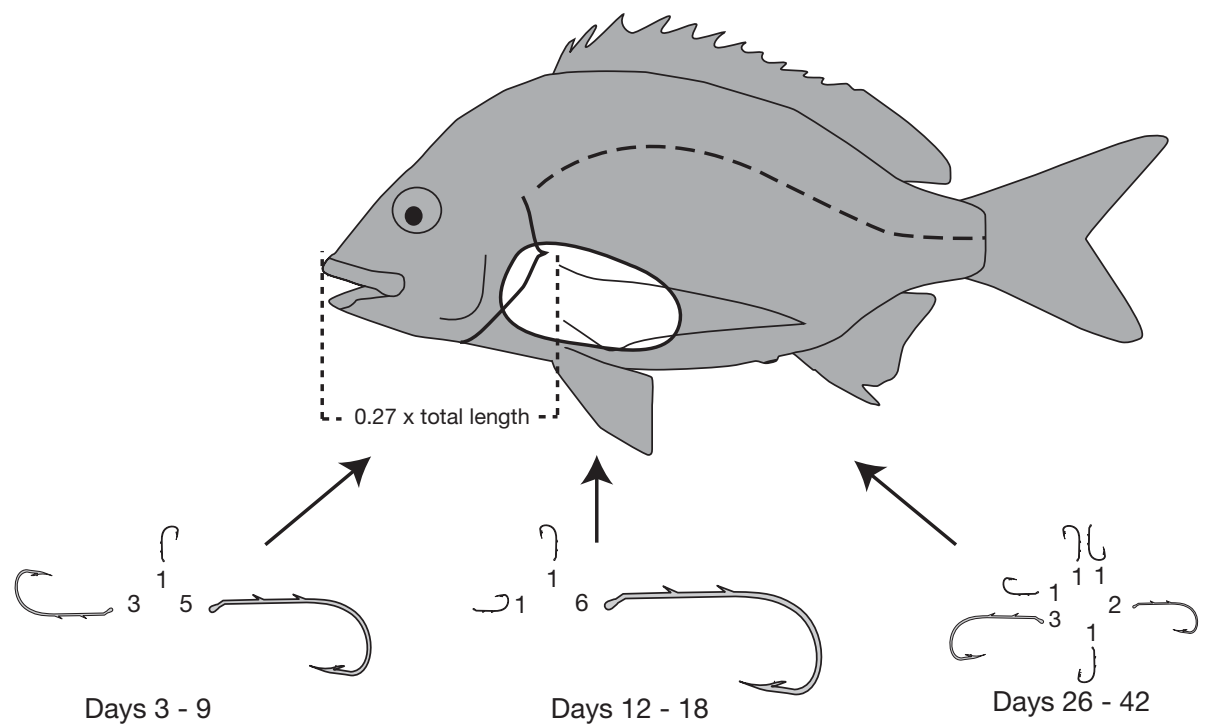

Fig. 4. Acanthopagrus australis. Two-dimensional orientation of hooks in yellowfin bream pooled across sampling occasions for 3 general periods during Expt 2. All ingested hooks were located in the white area, starting at an average distance of $0.27 \times$ total length $(\mathrm{cm})$ posterior to the snout. Sizes of hooks are proportional to the number observed at a particular orientation 
subsequent first-order interaction between sample time and the covariate $-\ln$ TL (Wilks' $\lambda_{4,23}=0.96, \mathrm{p}>$ 0.05). These interactions were sequentially removed from the model. A revised MANCOVA revealed significant main effects of the covariate (Wilks' $\lambda_{4,24}=0.08$, $\mathrm{p}<0.01$ ) and sample time (Wilks' $\lambda_{32,90}=0.13, \mathrm{p}<0.01$ ) and their interaction (Wilks' $\lambda_{32,90}=0.13, \mathrm{p}<0.01$ ). There was also a significant interaction between the main factors of interest: treatment of fish and sample time (Wilks' $\lambda_{32,90}=0.17, \mathrm{p}<0.05$ ). The subsequent ANCOVAs all revealed significant main effects of the covariate $(p<0.01)$. There were no other significant effects or interactions for $\ln \mathrm{MH}$ or $\ln \mathrm{MG}$ ( $\mathrm{p}>0.05)$, but there were significant interactions between the sample time and covariate for ln Wt $\left(F_{8,27}=4.43, \mathrm{p}<\right.$ $0.01)$, and between the treatment of fish and sample time for $\ln \mathrm{MW}\left(F_{8,27}=2.67, \mathrm{p}<0.05\right)$ and $\ln \mathrm{Wt}\left(F_{8,27}=\right.$ 2.33, $\mathrm{p}<0.05)$. Plots of the adjusted untransformed least-squares means $( \pm \mathrm{SE})$ for the latter interactions are presented in Fig. 5.

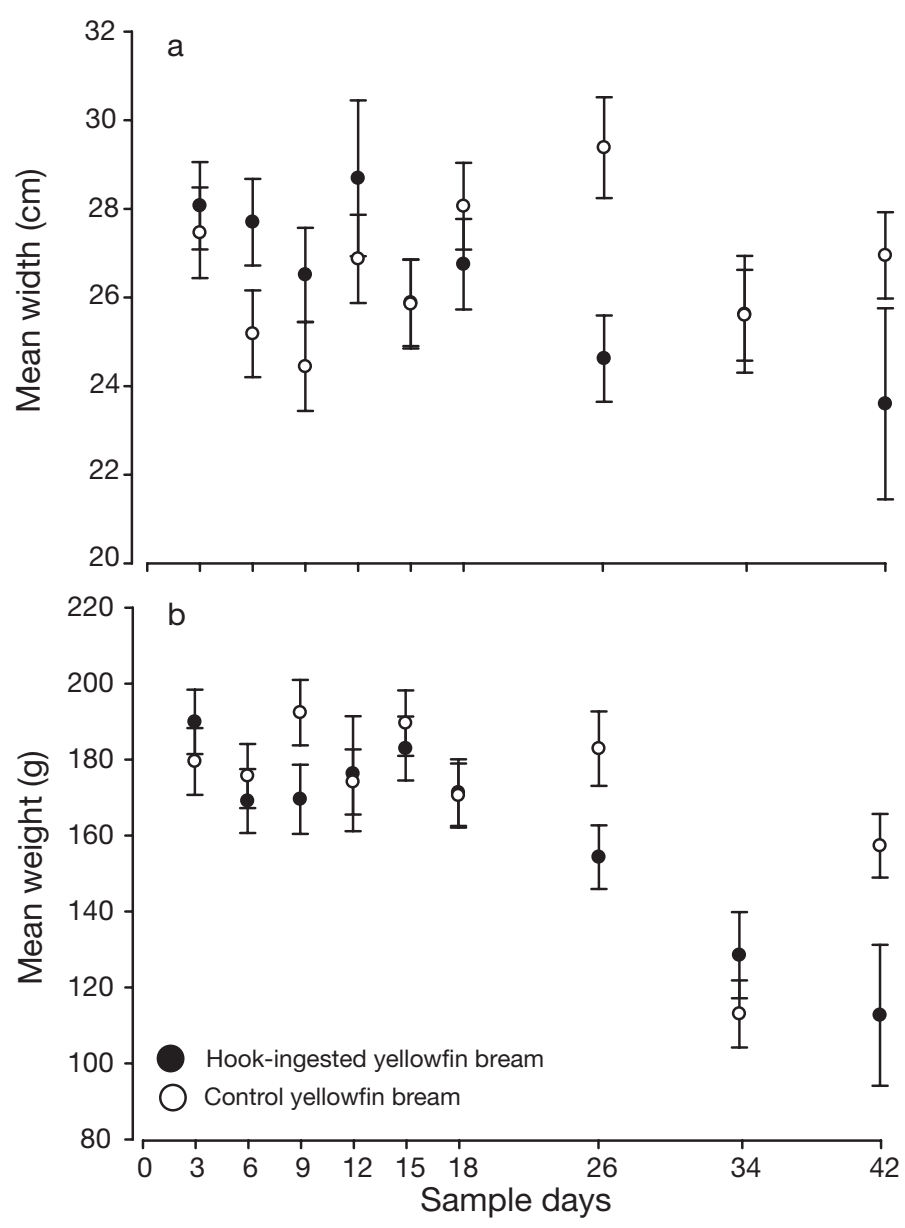

Fig. 5. Acanthopagrus australis. Differences in (a) maximum width (MW) and (b) weight (Wt) between hook-ingested and control yellowfin bream on 9 sampling occasions during Expt 2. Data are least-squares mean $\pm \mathrm{SE}$
The levels of glucose from fish in the 5 tanks prior to starting the experiment were not significantly different (ln-transformed data, $F_{4,10}=3.47, \mathrm{p}>0.05$ ), with a pooled mean of $2.30 \pm 0.44 \mathrm{mmol} \mathrm{l}^{-1}$ ). Differences were detected for cortisol (untransformed data, $F_{4,10}=4.63$, $\mathrm{p}<0.05)$, with fish from one of the control tanks having slightly elevated levels $\left(34.00 \pm 10.37 \mathrm{ng} \mathrm{ml}^{-1}\right)$ compared with the other 4 tanks (means between 0.09 and $12.31 \mathrm{ng} \mathrm{ml}^{-1}$ ).

Although we attempted to sample 3 hook-ingested and 3 control fish on each of the 9 sampling occasions, valid cortisol and glucose samples were obtained for only 2 individuals across most periods. Two-factor ANOVA returned a non-significant interaction between sampling occasion and treatment of fish (ln-transformed data, $F_{8,18}=1.91, \mathrm{p}>0.05$ ) and a nonsignificant main effect of the latter $\left(F_{1,18}=0.28, \mathrm{p}>\right.$ $0.05)$ for cortisol. There was a significant difference in cortisol among sampling occasions $\left(F_{8,18}=3.87\right.$, $\mathrm{p}<0.05)$, with all fish having elevated levels at the start and end of the experiment (Fig. 6a). In contrast, there were no significant effects of treatment (ln-transformed data, $\left.F_{8,18}=0.57, \mathrm{p}>0.05\right)$, sample time $\left(F_{8,18}=\right.$ $1.53, \mathrm{p}>0.05)$ or interaction $\left(F_{8,18}=1.48, \mathrm{p}>0.05\right)$ on glucose levels (Fig. 6b).

\section{DISCUSSION}

The mortalities to hook-ingested yellowfin bream observed in the present study validate short-term estimates from earlier field and aquaria studies (Butcher et al. 2007), and are within the range (0 to $41 \%$ ) recorded for other similarly hooked-and-released fish, including white seabass Atractoscion nobilis (Aalbers et al. 2004), snook Centropomus undecimalis (Taylor et al. 2001) and brown Salmo trutta (Hulbert \& EngstromHeg 1980) and rainbow trout Oncorhynchus mykiss (Mason \& Hunt 1967, Jenkins 2003). While there were relatively greater longer-term mortalities of fish during Expt 2, the results overall support the general trend in the few relevant published studies of stabilized mortalities after approximately $10 \mathrm{~d}$, followed by a protracted rate of hook ejection among most of the surviving individuals (Schill 1996, Schisler \& Bergersen 1996).

As reported for brown and rainbow trout (Hulbert \& Engstrom-Heg 1980, Schill 1996, Schisler \& Bergersen 1996), the specific mechanisms by which yellowfin bream ejected their hooks remain unclear. Their natural diet includes oysters (Ostreidae) and pipis Plebidonax spp. (Kailola et al. 1993), and so presumably their digestive tracts are accustomed to passing hard substances like shells. We did observe hook fragments and line being ejected from the anuses of 2 fish (at Days 5 and 12 post-release); however, the temporal 

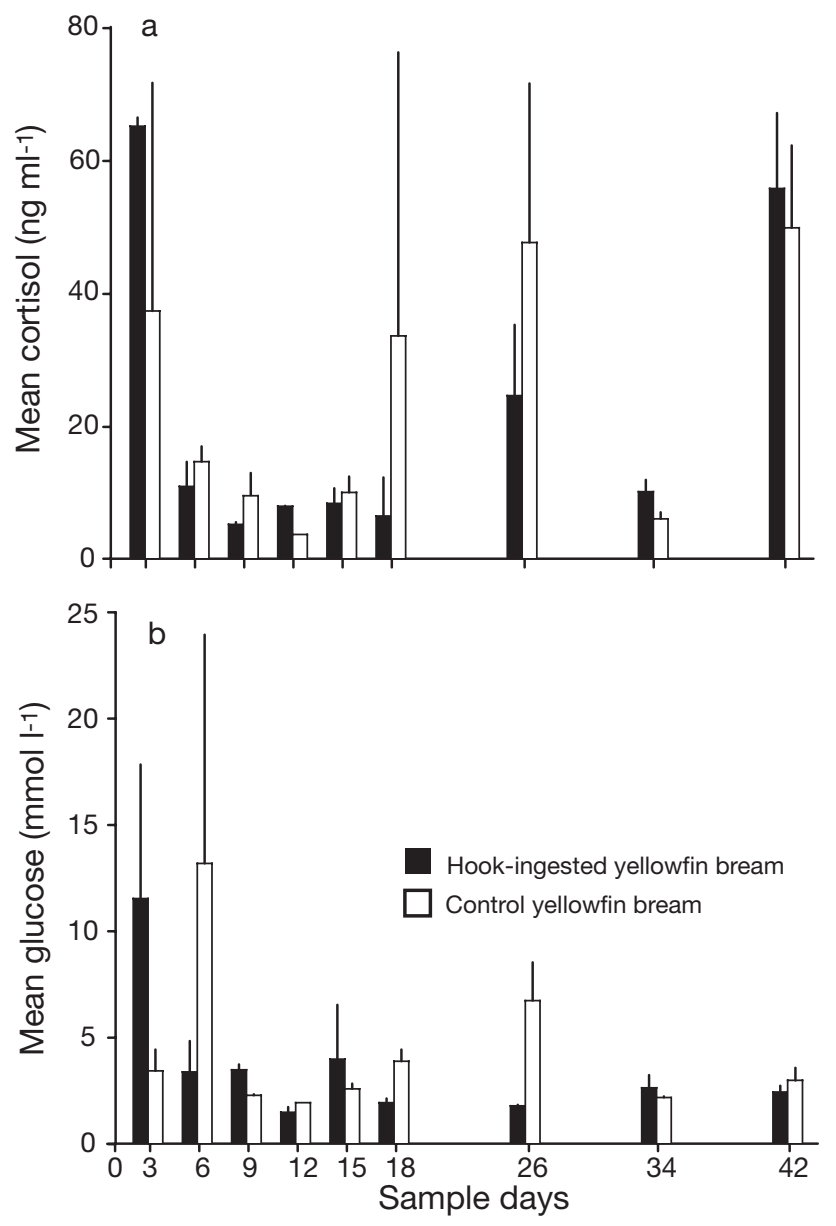

Fig. 6. Acanthopagrus australis. Differences in (a) plasma cortisol and (b) plasma glucose between hook-ingested and control yellowfin bream on 9 sampling occasions during Expt 2. Data are mean $+\mathrm{SE}$

analyses of relative hook positions during Expt 2 failed to detect any significant displacement, with most hooks remaining in the centre of the stomach, close to the mouth (Fig. 4). Further, after approximately 4 wk, many hooks appeared to re-orientate into positions less suitable for passage along the gastrointestinal tract (Fig. 4). This latter observation may also explain the delayed mortality of some fish, which likely occurred as ingested hooks were rotated or twisted in the stomach and possibly penetrated vital organs such as the heart and liver.

Irrespective of whether hooks were regurgitated from the mouth or passed through the anus, at least one contributing factor that seems to have facilitated ejection was their design and, more specifically, the presence of the bait holder barbs on the shaft (Fig. 1). While total hook corrosion was minimal (<approx. $6 \%$ reduction in weight after $6 \mathrm{wk}$ ), the points and barbs were rapidly oxidized owing to their relatively large surface area and less-protective nickel plating. This resulted in (1) points quickly becoming blunt and, in many cases, (2) hooks breaking at the base of the barbs on the shaft (often within $6 \mathrm{~d}$ ), where the diameter was narrower (up to approximately $15 \%$ ) than the rest of the hook. Ejected hooks were more frequently broken than tank hooks, probably because of torsion applied during re-orientation inside the digestive tract and/or ejection. These observations have implications for the future design of hooks. For example, it might be beneficial to increase the number of small diagonal cuts in the bend and shaft (like those used to make the barbs), so that oxidization occurs more quickly at these areas and separates the hook into smaller units that can be easily ejected by the fish. Alternatively, it may be appropriate to consider hooks with minimal or no anticorrosive coverings (Aalbers et al. 2004) so that the entire hook oxidizes rapidly in the digestive tract; however, this would require at least some concomitant assessment of the effects of large-scale steel oxidation on fish health.

It is apparent that the ingested nickel-plated carbonsteel hooks examined in this study had few overall impacts on the short- and long-term physiology and general health of yellowfin bream. Although there were considerable fluctuations in primary and secondary stress responses during the experiments, many of these can be attributed to the overall experimental design, and especially the confinement of fish, rather than to the ingestion/ejection of hooks. This is clearly illustrated by the analyses of plasma cortisol and glucose at the start of both experiments. Baseline levels of these variables from wild yellowfin bream have been previously estimated at $3.6 \pm 2.0 \mathrm{ng} \mathrm{ml}^{-1}$ and $1.3 \pm$ $0.4 \mathrm{mmol} \mathrm{l}^{-1}$, respectively (Butcher et al. 2007), and are similar to other sparids (Pankhurst \& Sharples 1992, Rotllant \& Tort 1997). Most of the sampled fish in the 30001 holding tanks at the start of the experiments maintained plasma glucose at baseline levels, but had elevated and often variable concentrations of cortisol (up to a mean $\pm \mathrm{SE}$ of $37.99 \pm 7.57 \mathrm{ng} \mathrm{ml}^{-1}$ ), indicating acute responses to stressors that were possibly evoked during their capture. More specifically, individuals had to be consecutively hooked from the same tanks, and this may have stressed their conspecifics.

The similar cortisol and glucose levels for hookingested and control fish in the $110 \mathrm{l}$ experimental tanks at the start and end of both experiments probably reflected their isolation in confinement. Yellowfin bream are a schooling species and so the absence of any social interactions in the $110 \mathrm{l}$ tanks could have contributed to the stress associated with their removal from the larger holding tanks, irrespective of whether they were hooked or scooped. Many fish showed a variable but slightly protracted recovery from stress during Expt 2, with cortisol elevated in both groups on 
Day 3 and glucose elevated in hook-ingested and control fish on Days 3 and 6 respectively (Fig. 6). Both groups appeared to have adjusted to the $110 \mathrm{l}$ tanks after the first week, but there was considerable temporal variation in their acute stress responses, as evidenced by fluctuations in concentrations of cortisol (Fig. 6). Such variability could reflect the movements of researchers in the vicinity of fish during sampling.

Notwithstanding the acute stress responses discussed above, all yellowfin bream consumed and assimilated food soon after being placed in the 1101 tanks. This was confirmed by observations of fish feeding and faecal matter in the bottom of the tanks, and is further supported by the diet analyses done at the end of Expt 1. No differences were detected in the ADCs of protein and dry matter between hook-ingested/ejected and control fish at the end of the $105 \mathrm{~d}$ monitoring period and, equally important, there was an increase in ADCs between the anterior and posterior intestine, indicating progressional nutrient assimilation. Also, the morphological parameters of the 17 hook-ingested/-ejected fish surviving to the end of Expt 1 were not significantly different to those of the 20 control fish.

All of the surviving treatment fish in Expt 1 had ejected their hooks more than $7 \mathrm{wk}$ before they were sampled, which may have been sufficient time for them to recover from any whole body stress responses, such as a reduced ability to consume, digest and assimilate food. In support of this, there were significant short- to medium-term morphological differences between hook-ingested and control fish during Expt 2, identified as a significant interaction with sampling time for $\mathrm{MH}$ and Wt (Fig. 5). Compared with control fish, hook-ingested individuals were generally wider until Day 15 post-release, after which they were mostly narrower. Mean weight remained similar between hook-ingested and control fish until Day 26, when it declined in both, but generally at a greater rate for hook-ingested fish. One explanation for the slightly greater MW in hook-ingested fish during the first $2 \mathrm{wk}$ is some initial inflammation or swelling associated with the presence of the hook in the stomach. Any mild swelling or distortion of the stomach would not necessarily have effectuated a corresponding increase in mean weight. It is unknown what proportion of the fish sampled in Expt 2 would have eventually ejected or continued to retain their hooks, but given the data from Expt 1, it is likely that over the longer term their morphological condition would have returned to levels similar to those of control fish.

In conclusion, the results from this study clearly illustrate that cutting the line and releasing yellowfin bream that have ingested nickel-plated carbon-steel J-hooks is an appropriate strategy for minimizing their unwanted mortality, with minimal negative long-term effects on their health. However, further research is required to examine the fate of these individuals in the wild, especially the potential for mortality from predation or infection as a consequence of short- to mediumterm stress and changes in behaviour and physical condition (Pickering \& Pottinger 1985, Ryer 2004). It is also important to consider that while this and earlier research (Butcher et al. 2007) has shown that the greater majority of released, line-cut hook-ingested yellowfin bream survive, mortalities can be virtually eliminated if hooking is restricted to the mouth and jaw. For this reason, future research should also include detailed investigation of alternative hook designs (e.g. Willis \& Millar 2001) that limit the rates of ingestion.

Acknowledgements. Funding for this study was provided by the NSW Department of Primary Industries (DPI) and the NSW Recreational Fishing Trust. Research was approved by the DPI Animal Care and Ethics Committee (ACEC REF 05/02). We thank M. Booth, M. Timmins, S. McGrath, A. Hulme, G. Allan and S. Fielder for their scientific support and $\mathrm{S}$. Cairns for guidance and assistance with analyses.

\section{LITERATURE CITED}

Aalbers SA, Stutzer GM, Drawbridge MA (2004) The effects of catch-and-release angling on the growth and survival of juvenile white seabass captured on offset circle and J-type hooks. N Am J Fish Manag 24:793-800

Allan GL, Rowland SJ, Parkinson S, Stone DA, Jantrarotai J (1999) Nutrient digestibility for juvenile silver perch Bidyanus bidyanus: development of methods. Aquaculture 170:131-145

AOAC (1975) Official methods of analysis of the association of official analytical chemists, 12th edn. AOAC, Washington, DC

Austreng E (1978) Digestibility determination in fish using chromic oxide marking and analysis of contents from different segments of the gastrointestinal tract. Aquaculture 13:265-272

Bartholomew A, Bohnsack JA (2005) A review of catch-andrelease angling mortality with implications for no-take reserves. Rev Fish Biol Fish 15:129-154

Barton BA (1997) Stress in finfish: past, present and futurea historical perspective. In: Iwama GK, Pickering $A D$, Sumpter JP, Schreck CB (eds) Fish stress and health in aquaculture. Cambridge University Press, Cambridge, p 1-33

Broadhurst MK, Barker DT, Kennelly SJ (1999) Scale-loss and survival of juvenile yellowfin bream, Acanthopagrus australis, after simulated escape from a Nordmøre-grid guiding panel and release from capture by hook and line. Bull Mar Sci 64:255-268

Broadhurst MK, Gray CA, Reid DD, Wooden MEL, Young DJ, Haddy JA, Damiano C (2005) Mortality of key fish species released by recreational anglers in an Australian estuary. J Exp Mar Biol Ecol 321:171-179

Broadhurst MK, Dijkstra K, Reid DD, Gray CA (2006) Utility of morphological data for key species in southeastern Aus- 
tralian coastal otter trawl and seine fisheries. NZ J Mar Freshw Res 40:259-272

Butcher PA, Broadhurst MK, Reynolds D, Reid DD, Gray CA (2007) Release method and anatomical hook location: effects on short-term mortality of angler-caught Acanthopagrus australis and Argyrosomus japonicus. Dis Aquat Org 74:17-26

Carragher JF, Rees CM (1994) Primary and secondary stress responses in golden perch, Macquaria ambigua. Comp Biochem Physiol 107A:49-56

Cho CY, Kaushik SJ (1990) Nutritional energetics in fish: energy and protein utilization in rainbow trout (Salmo gairdneri). 61:132-172

Henry GW, Lyle JM (2003) The national and indigenous fishing survey. NSW Fisheries, Cronulla

Hulbert PJ, Engstrom-Heg R (1980) Hooking mortality of worm-caught hatchery brown trout. NY Fish Game J 27: $1-10$

Jenkins TM (2003) Evaluating recent innovations in bait fishing tackle and technique for catch and release of rainbow trout. N Am J Fish Manag 23:1098-1107

Kailola PJ, Williamson MJ, Stewart PC, Reichelt RE, McNee A, Grieve C (1993) Australian fisheries resources. Bureau of Resources Sciences, Canberra

Mason JW, Hunt L (1967) Mortality rates of deeply hooked rainbow trout. Prog Fish-Cult 29:87-91

Mazeaud MM, Mazeaud F, Donaldson EM (1977) Primary and secondary effects of stress in fish: some new data with a general review. Trans Am Fish Soc 106:201-212

Moore DA (1983) Use of mutarotase to improve Trinder assay of glucose in serum and plasma. American Association for Clinical Chemistry 35th National Meeting, New York, NY, July 24-29 1983. Clin Chem 1983 29:1156-1287 (Abstract)

Muoneke MI, Childress WM (1994) Hooking mortality: a review for recreational fisheries. Rev Fish Sci 2:123-156

Pankhurst NW, Sharples DF (1992) Effects of capture and confinement on plasma cortisol concentrations in the snapper, Pagrus auratus. Aust J Mar Freshw Res 43:345-356

Pickering AD, Pottinger TG (1985) Cortisol can increase the susceptibility of brown trout Salmo trutta L., to disease

Editorial responsibility: Anne Skiftesvik, Storebø, Norway without reducing the white blood cell count. J Fish Biol 27: 611-619

Pickering AD, Pottinger TG, Christie P (1982) Recovery of the brown trout, Salmo trutta L., from acute handling stress: a time course study. J Fish Biol 20:229-244

Rotllant J, Tort T (1997) Cortisol and glucose responses after acute stress by net handling in the sparid red porgy previously subjected to crowding stress. J Fish Biol 51:21-28

Ryer CH (2004) Laboratory evidence for behavioural impairment of fish escaping trawls: a review. ICES J Mar Sci 61: $1157-1164$

Schill DJ (1996) Hooking mortality of bait-caught rainbow trout in an Idaho trout stream and a hatchery: implications for special-regulation management. N Am J Fish Manag 16:348-356

Schisler GJ, Bergersen EP (1996) Postrelease hooking mortality of rainbow trout caught on scented artifical baits. N Am J Fish Manag 16:570-578

Scott K (1978) Cause and control of losses of chromium during nitric-perchloric acid oxidation of aquatic sediments. Analyst 103:754-758

Taylor RG, Whittington JA, Haymans DE (2001) Catch-andrelease mortality rates of common snook in Florida. N Am J Fish Manag 21:70-75

Tsuboi J, Morita K, Ikeda H (2006) Fate of deep-hooked white-spotted charr after cutting the line in a catch-andrelease fishery. Fish Res 79:226-230

Wedemeyer G, McLeay DJ (1981) Methods for determining the tolerance of fishes to environmental stressors. In: Pickering $\mathrm{AD}$ (ed) Stress and fish. Academic Press, London, p 247-275

West RJ, Gordon GNG (1994) Commercial and recreational harvest of fish from two Australian coastal rivers. Aust J Mar Freshw Res 45:1259-1279

Willis TJ, Millar RB (2001) Modified hooks reduce incidental mortality of snapper (Pagrus auratus: Sparidae) in the New Zealand commercial longline fishery. ICES J Mar Sci 58: 830-841

Underwood AJ (1981) Techniques of analysis of variance in experimental marine biology and ecology. Oceanogr Mar Biol Annu Rev 19:513-605

Submitted: June 13, 2006; Accepted: November 14, 2006

Proofs received from author(s): January 22, 2007 